\title{
Influence of dose reduction and iterative reconstruction on CT calcium scores: a multi-manufacturer dynamic phantom study
}

\author{
N. R. van der Werf $^{1,2} \cdot$ M. J. Willemink ${ }^{2}$ T. P. Willems ${ }^{1} \cdot$ M. J. W. Greuter ${ }^{1} \cdot$ \\ T. Leiner ${ }^{2}$
}

Received: 19 August 2016 / Accepted: 2 January 2017 / Published online: 19 January 2017

(C) The Author(s) 2017. This article is published with open access at Springerlink.com

\begin{abstract}
To evaluate the influence of dose reduction in combination with iterative reconstruction (IR) on coronary calcium scores (CCS) in a dynamic phantom on state-ofthe-art CT systems from different manufacturers. Calcified inserts in an anthropomorphic chest phantom were translated at $20 \mathrm{~mm} / \mathrm{s}$ corresponding to heart rates between 60 and $75 \mathrm{bpm}$. The inserts were scanned five times with routinely used CCS protocols at reference dose and 40 and $80 \%$ dose reduction on four high-end CT systems. Filtered back projection (FBP) and increasing levels of IR were applied. Noise levels were determined. CCS, quantified as Agatston and mass scores, were compared to physical mass and scores at FBP reference dose. For the reference dose in combination with FBP, noise level variation between CT systems was less than $18 \%$. Decreasing dose almost always resulted in increased CCS, while at increased levels of IR, CCS decreased again. The influence of IR on CCS was smaller than the influence of dose reduction. At
\end{abstract}

N. R. van der Werf

n.r.vanderwerf@umcutrecht.nl

M. J. Willemink

m.willemink@umcutrecht.nl

T. P. Willems

t.p.willems@umcg.nl

M. J. W. Greuter

m.j.w.greuter@umcg.nl

T. Leiner

t.leiner@umcutrecht.nl

1 Department of Radiology, University Medical Center Groningen, University of Groningen, Hanzeplein 1, 9713 GZ Groningen, The Netherlands

2 Department of Radiology, University Medical Center Utrecht, Heidelberglaan 100, 3584 CX Utrecht, The Netherlands reference dose, physical mass was underestimated 3-30\%. All CT systems showed similar CCS at $40 \%$ dose reduction in combinations with specific reconstructions. For some CT systems CCS was not affected at $80 \%$ dose reduction, in combination with IR. This multivendor study showed that radiation dose reductions of $40 \%$ did not influence CCS in a dynamic phantom using state-of-the-art CT systems in combination with specific reconstruction settings. Dose reduction resulted in increased noise and consequently increased CCS, whereas increased IR resulted in decreased CCS.

Keywords Computed tomography · Coronary calcium . Calcium score $\cdot$ Low dose CT $\cdot$ Iterative reconstruction CT
Abbreviations
CCS Coronary calcium score
CT Computed tomography
FBP Filtered back projection
HA Hydroxyapatite
HU Hounsfield units
IR Iterative reconstruction

\section{Introduction}

The coronary calcium score (CCS) is known to be a strong predictor for major adverse cardiovascular events [1, 2]. Computed tomography (CT) is the first modality of choice for assessment of the presence and quantification of calcium in the coronary arteries. The number of CCS examinations with $\mathrm{CT}$ is expanding rapidly [3]. However, due to the expanding use of ionizing radiation in medicine, CT has become the main source of increased population dose in Western countries [4]. This dose issue is especially 
important when considering the 2013 guidelines from the American Heart Association that recommend CCS measurements if, after quantitative risk assessment, the riskbased treatment decision is uncertain in asymptomatic adults at intermediate and low-to-intermediate risk [5].

Recently, iterative reconstruction (IR) has become widely available on commercially available CT systems. IR allows for a dose reduction without the typical decrease in image quality [6-8]. It may therefore be possible to quantify CCS at lower dose levels, when using IR. Recent studies found that application of IR can result in spurious decreases in CCS in comparison with conventionally used filtered back projection (FBP) [9-11]. These effects of dose reduction and IR on CCS can be explained by their effect on image noise. At decreased dose an increase in noise is expected. This increase in noise can be associated with an increase in voxels above the calcium threshold of 130 Hounsfield Units (HU), which in turn increases CCS. Conversely, a decrease in CCS is expected with IR since it reduces noise [12-15].

Moreover, cardiac motion imposes problems for the stability of CCS since calcium can be blurred and CCS can be over- or underestimated, depending on the density of the calcification [16-18]. The combined effects of dose reduction, IR and heart rate on CCS for all major manufacturers have not been investigated before in a phantom study.

Therefore, the objective of this study was to evaluate the influence of dose reduction in combination with IR on CCS of moving calcifications in coronary CT on state-of-the-art $\mathrm{CT}$ systems from different manufacturers.

\section{Materials and methods}

An anthropomorphic chest phantom (Thorax, QRM, Moehrendorf, Germany) with artificial lungs, a spine insert and a shell of soft tissue equivalent material was used $[16,17]$. An extension ring of tissue equivalent material was placed around the chest to simulate an averaged sized patient of $400 \times 300 \mathrm{~mm}(\mathrm{QRM}$-Extensionring, QRM, Germany) [19]. The center compartment of the phantom was filled with water in which a motion simulator (Sim2D, QRM, Moehrendorf, Germany) translated an artificial coronary artery with two calcium hydroxyapatite (HA) inserts. The inserts had densities of $196 \pm 3,380 \pm 2,408 \pm 2$ and $800 \pm 2 \mathrm{mg} \mathrm{HA} / \mathrm{cm}^{3}$ and masses of $38.5 \pm 1.7,74.6 \pm 3.1$, $80.1 \pm 3.3$ and $157.1 \pm 6.5 \mathrm{mg}$ HA, respectively (Appendices 2,3 ).

All inserts had equal dimensions; length $10.0 \pm 0.1 \mathrm{~mm}$, diameter $5.0 \pm 0.1 \mathrm{~mm}$, volume $196.3 \pm 8.1 \mathrm{~mm}^{3}$. The artificial arteries were linearly translated in the horizontal plane at a velocity of $20 \mathrm{~mm} / \mathrm{s}$ perpendicular to the scan direction. This velocity is comparable to typical velocities of the left anterior descending and right coronary arteries during the late diastolic scan phase of the R-R interval, at heart rates between 60 and 75 bpm [20, 21].

In order to assess the influence of IR and dose reduction on CCS in a clinical setting, daily used clinical CT protocols for coronary calcium scoring were used. These protocols were equal to the vendor recommended protocols if available or were adapted based on recommendation by the specific manufacturer consultants. Four different state-ofthe-art CT systems (referred to as S1-S4) were used: Discovery CT 750 HD (GE Healthcare, Waukesha, Wisconsin, USA), Brilliance iCT (Philips Healthcare, Best, The Netherlands), Somatom Definition Flash (Siemens Healthcare, Forchheim, Germany) and Aquilion One (Toshiba Medical Systems, Otawara, Japan), respectively (Table 1).

The phantom was scanned at three dose levels by reduction of the tube current: a reference dose at $100 \%$ tube current, and at reduced dose levels of 40 and $80 \%$ reduced tube current. Each scan was repeated five times
Table 1 Acquisition and reconstruction parameters used on CT system $\mathrm{S} 1-\mathrm{S} 4$

\begin{tabular}{lllll}
\hline CT system & S1 & S2 & S3 & S4 \\
\hline Tube voltage (kV) & 120 & 120 & 120 & 120 \\
Tube charge per rotation (mA) & 500 & 185 & 285 & 230 \\
Collimation (mm) & $64 \times 0.625$ & $128 \times 0.625$ & $128 \times 0.6$ & $320 \times 0.5$ \\
Rotation time (s) & 0.35 & 0.27 & 0.28 & 0.35 \\
Temporal resolution ${ }^{\mathrm{a}}(\mathrm{ms})$ & 175 & 135 & 75 & 175 \\
Slice thickness (mm) & 2.5 & 3.0 & 3.0 & 3.0 \\
Increment (mm) $_{\text {Kernel }}$ & 2.5 & 3.0 & 3.0 & 3.0 \\
Levels of IR $_{\text {Noise level (HU) }}$ & Standard & XCA & B35f & FC12 \\
CTDI & $20,60,100 \%$ & $1,5,7$ & $1,3,5$ & weak, standard, strong \\
Software & 26 & 22 & 28 & 24 \\
\hline
\end{tabular}

${ }^{\mathrm{a} A s}$ defined in the isocenter 
with a small translation $(2 \mathrm{~mm})$ and rotation $\left(2^{\circ}\right)$ between each scan by manually repositioning the phantom. The internal ECG signal of the motion controller was used to simulate the heart rate of the patient and used as ECG trigger on all four CT systems. The triggering was carefully timed so that data acquisition was during linear motion of the phantom.

Images were reconstructed with FBP, and three increasing levels of IR: the lowest (L1), an intermediate (L2) and the highest level available on the CT system (L3) (Table 1). For each data set the noise level in the images was assessed by calculating the standard deviation in the average Hounsfield value in a uniform water region. The amount of calcium of each insert was quantified as Agatston and mass scores with manufacturerrecommended software (Table 1) with a default threshold of 130 Hounsfield units (HU). A semi-automatic method was used for selecting the calcification by one observer. On each CT system, the mass score calibration factors were determined as described by McCollough et al. [19]. Although mass scores are not used clinically, they were included for this study because of its potential to compare the score to the physical mass.

The design of this study resulted in 480 calcium scores per CT system (5 acquisitions at 3 dose levels with 4 reconstruction types for 4 calcifications and 2 calcium scores).

Agatston score and mass score were expressed as median and 25th-75th percentile for each calcification insert and CT system. For each insert, CCS from both the iteratively reconstructed and FBP reconstructed data sets for reduced dose levels were compared to the CCS from the FBP reconstructed data sets at reference dose using a Wilcoxon signed rank test. All statistical analyses were performed with SPSS for Windows, version
22.0. A p value of 0.05 was used to determine significant differences.

\section{Results}

\section{Influence of dose reduction and iterative reconstruction on noise}

For all CT systems and all reconstructions, a decrease in dose resulted in a vendor dependent increase in noise, whereas IR led to a decrease in noise (Fig. 1). Also, although the $\mathrm{CTDI}_{\mathrm{vol}}$ differed at most with a factor of 3.8 between the CT systems, the noise levels varied less than $18 \%$ at FBP reference dose.

\section{Influence of dose reduction on Agatston score with FBP}

Dose reduction resulted in significant increases in Agatston scores for almost all calcifications and CT systems (Fig. 2). This increase, in combination with an increase in noise, is depicted in the top row of Fig. 3.

For S1 at FBP and averaged over all inserts, Agatston scores increased by 8 and $25 \%$ at 40 and $80 \%$ reduced dose respectively. For the other CT systems similar increases in Agatston scores at FBP were observed at reduced dose with a corresponding average increase of 7 and $64 \%$ for S2, 4 and 26\% for S3, and 1 and 23\% for S4. The largest increase in Agatston score at reduced dose was observed for the $38 \mathrm{mg}$ insert at $80 \%$ dose reduction: $58,160,48$, and 71 for S1-S4, respectively.

\section{Influence of dose reduction on mass score with FBP}

Also, dose reductions resulted in significantly increased mass scores at FBP for almost all inserts and CT systems,
Fig. 1 Average noise levels in a uniform water region for images reconstructed with filtered back projection (FBP) and increasing levels of IR L1, L2 and L3 as measured on CT systems $\mathrm{S} 1$, S2, S3 and S4. For each combination of reconstruction method and CT system box plots are shown for the average noise level at reference dose, and 40 and $80 \%$ reduced dose

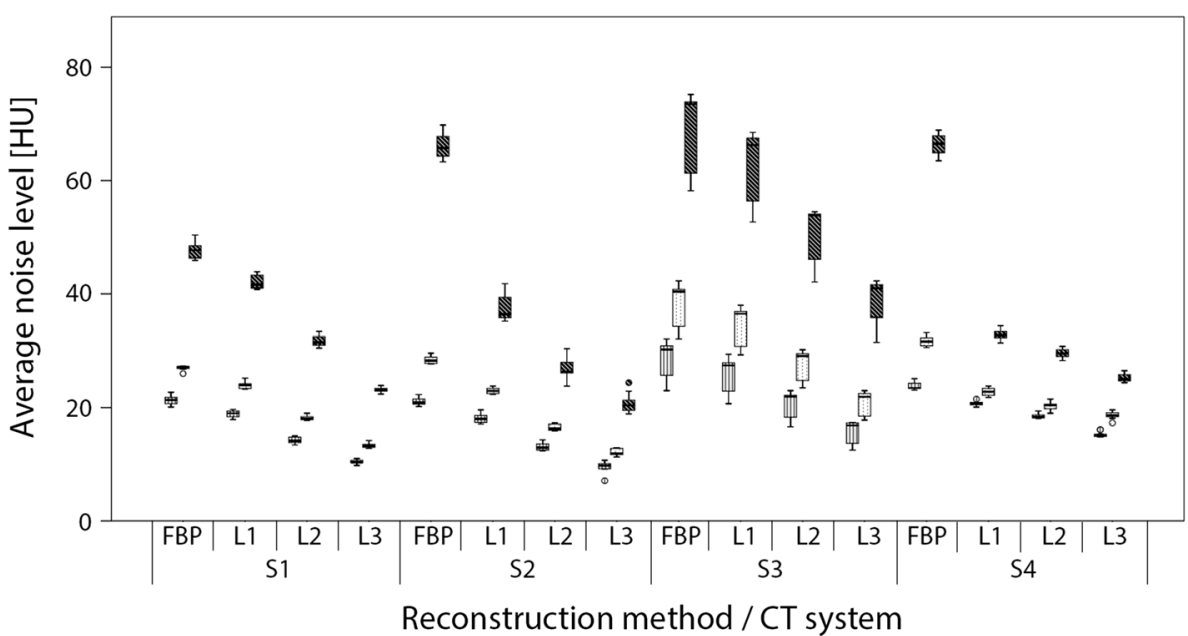




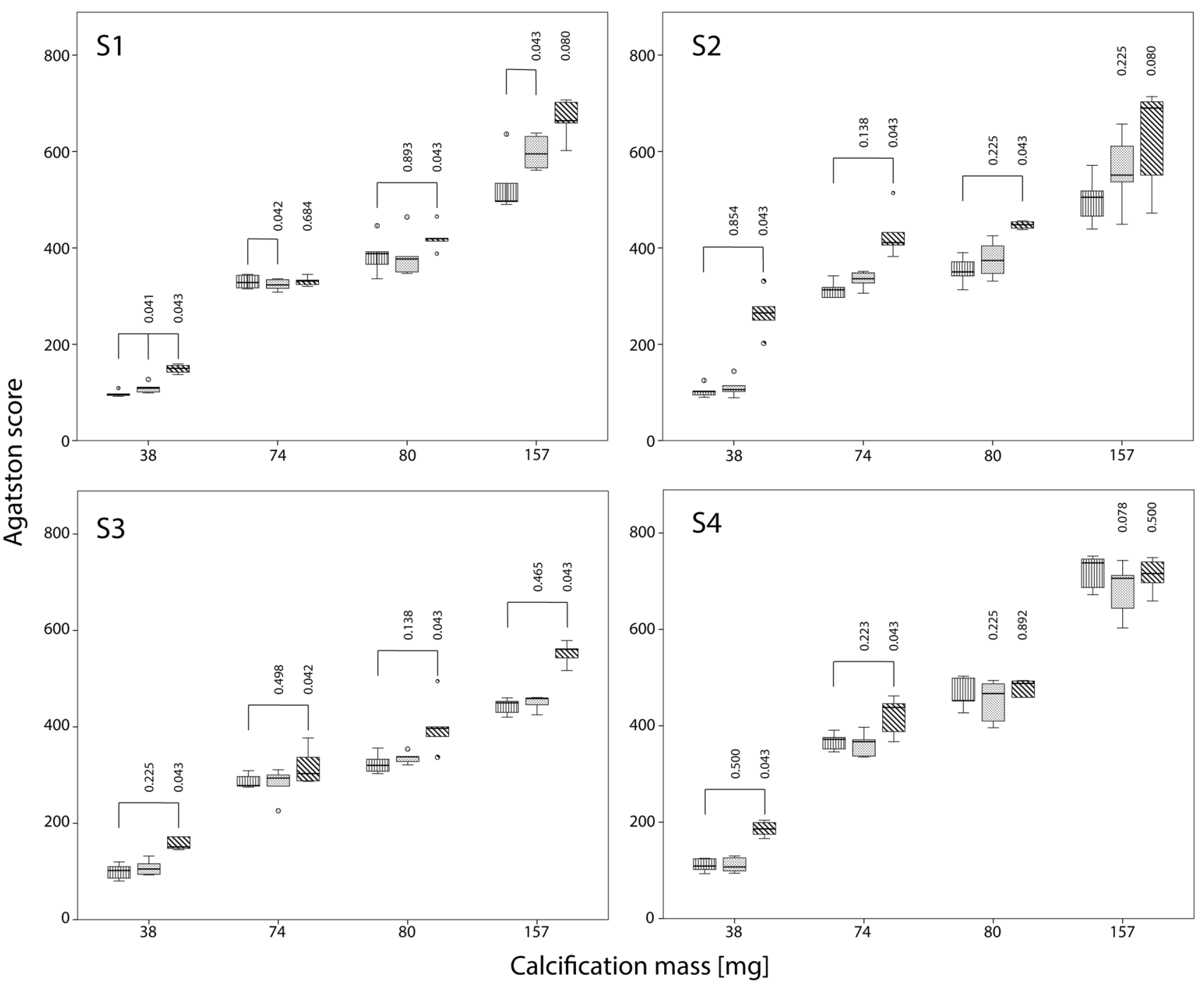

Fig. 2 Influence of dose reduction on Agatston score for S1-S4 with FBP. The movement of the calcification corresponds to displacements seen with heart rates of 60-75 bpm. For calcifications of 38, 74, 80 and $157 \mathrm{mg}$ box plots of the Agatston score at reference dose, and at

albeit that the increase was smaller than the increase in Agatston scores (Fig. 4).

At $40 \%$ reduced dose, mass scores increased on average by $0,3,1$ and $0 \%$ for S1-S4 respectively in comparison with the mass score at reference dose. At $80 \%$ reduced dose, mass scores increased 35, 15 and $13 \%$ for S2-S4, whereas for $\mathrm{S} 1$ the mass score decreased $11 \%$.

\section{Influence of iterative reconstruction on Agatston scores}

With increased IR levels, a significant decrease in Agatston scores was observed for almost all calcifications and CT systems (Fig. 5). This decrease in Agatston score was accompanied by decrease in noise, as can be seen from the left column in Fig. 3.
40 and $80 \%$ reduced dose are shown. Agatston scores are compared with the Agatston score at reference dose using the Wilcoxon signed rank test. Significant different Agatston scores are indicated by brackets

Averaged over all inserts, Agatston scores for S1 decreased on average 0,2 and 5\% at L1-L3 respectively. For S2 the corresponding decrease was 1, 4, and 5\%; for S3 1, 4, and 9\% and for S4 1, 4, and 7\%. The largest decrease in Agatston score was again observed for the 38 mg calcification: $22 \%$ with L3 on S3, and $19 \%$ with L3 on S4.

\section{Influence of iterative reconstruction on mass scores}

The decrease in mass scores at increased levels of IR was smaller than the observed decrease in Agatston scores (Fig. 6). Mass score decreased on average between 0 and $6 \%$ for all CT systems and inserts. 
Fig. 3 Reconstructed images of a $3.0 \mathrm{~mm}$ slice of the $38 \mathrm{mg}$ insert moving at $20 \mathrm{~mm} / \mathrm{s}$ on $\mathrm{S} 2$. Data was acquired at reference dose, and at 40 and $80 \%$ dose reduction (from left to right) and reconstructed with filtered back projection and increasing levels of IR L1, L2 and L3 (from top to bottom). CCS were included as Agatston score/mass score. Noise levels (SD) are expressed as Hounsfield Units. Window center was $90 \mathrm{HU}$ and window width was $750 \mathrm{HU}$

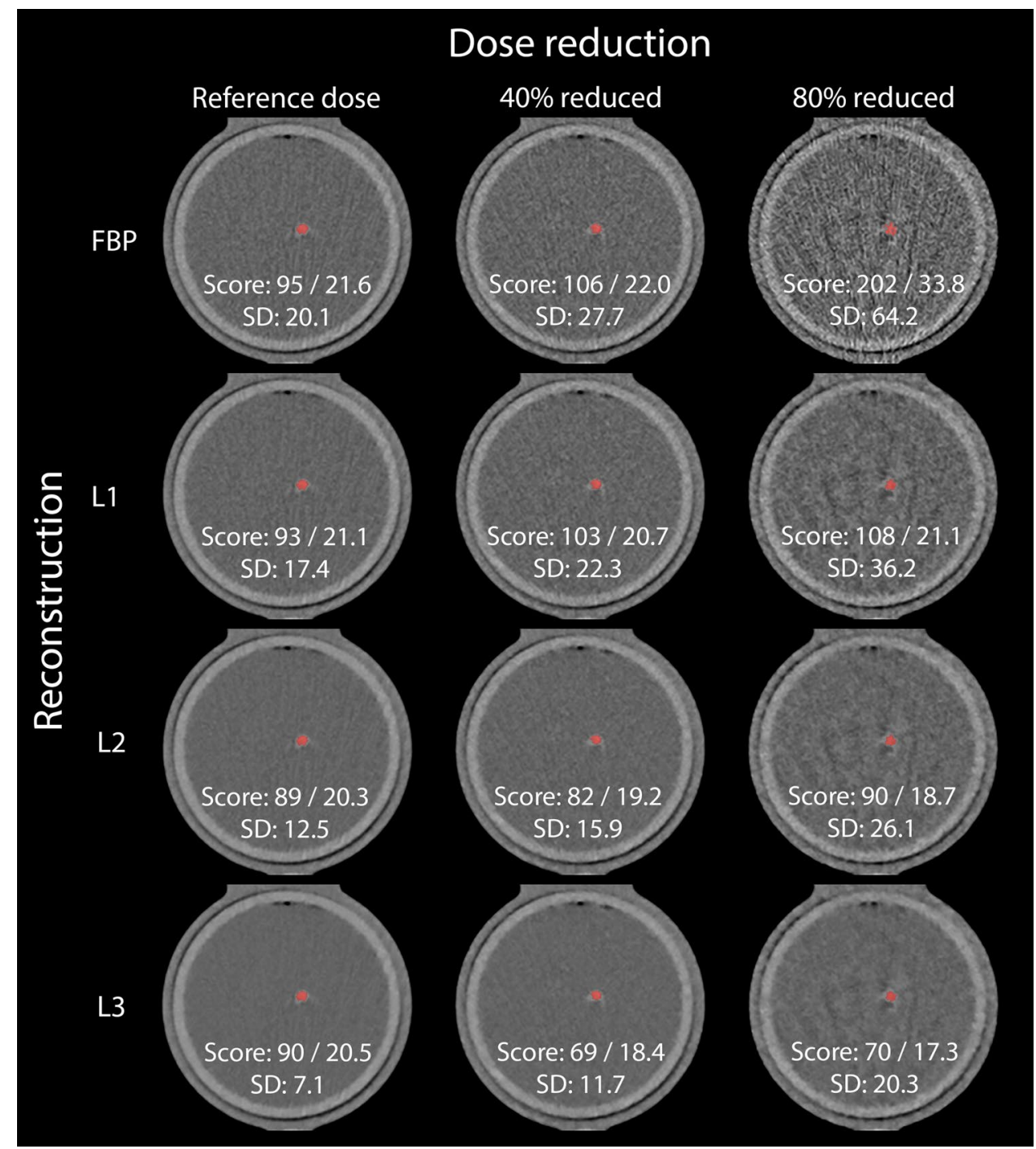

\section{Combination of dose reduction and iterative reconstruction on Agatston and mass scores}

Representative images of the reconstructed datasets are shown in Fig. 3.

For all four CT systems $40 \%$ dose reduction in combination with varying levels of IR did not result in significantly different Agatston and mass scores with respect to the reference dose (Table 2). For $80 \%$ dose reduction, only S2 in combination with L2 and L3 did not result in significantly different Agatston scores. For the other CT systems, there was no combination of investigated imaging parameters that resulted in Agatston scores which were unchanged from the reference protocol and dose.

On all CT systems, mass scores generally underestimated the physical mass of the calcifications. Mass scores at FBP and reference dose and deviations from the physical mass are listed in Table 3. Averaged over all inserts the physical mass was underestimated by $23,12,30$, and $3 \%$ for
S1-S4 respectively. The largest underestimation was again observed for the $38 \mathrm{mg}$ insert, where the underestimation was $39,33,30$, and $31 \%$, respectively for $\mathrm{S} 1-\mathrm{S} 4$. At $40 \%$ reduced dose the underestimation was $24,9,29$, and $3 \%$. At $80 \%$ reduced dose the underestimation was 24 and $29 \%$ on S1 and S3, whereas S2 and S4 showed an overestimation of on average 16 and $9 \%$. The influence of IR on mass scores was relatively small compared to the influence of dose reduction. At the maximum IR level, the underestimation of the physical mass at reference dose was $23,15,32$, and $8 \%$ for S1-S4, respectively (averaged over all inserts).

\section{Discussion}

To our knowledge this is the first multivendor study to evaluate the effects of dose reduction and IR on CCS in a dynamic phantom. We have shown that dose reduction in 


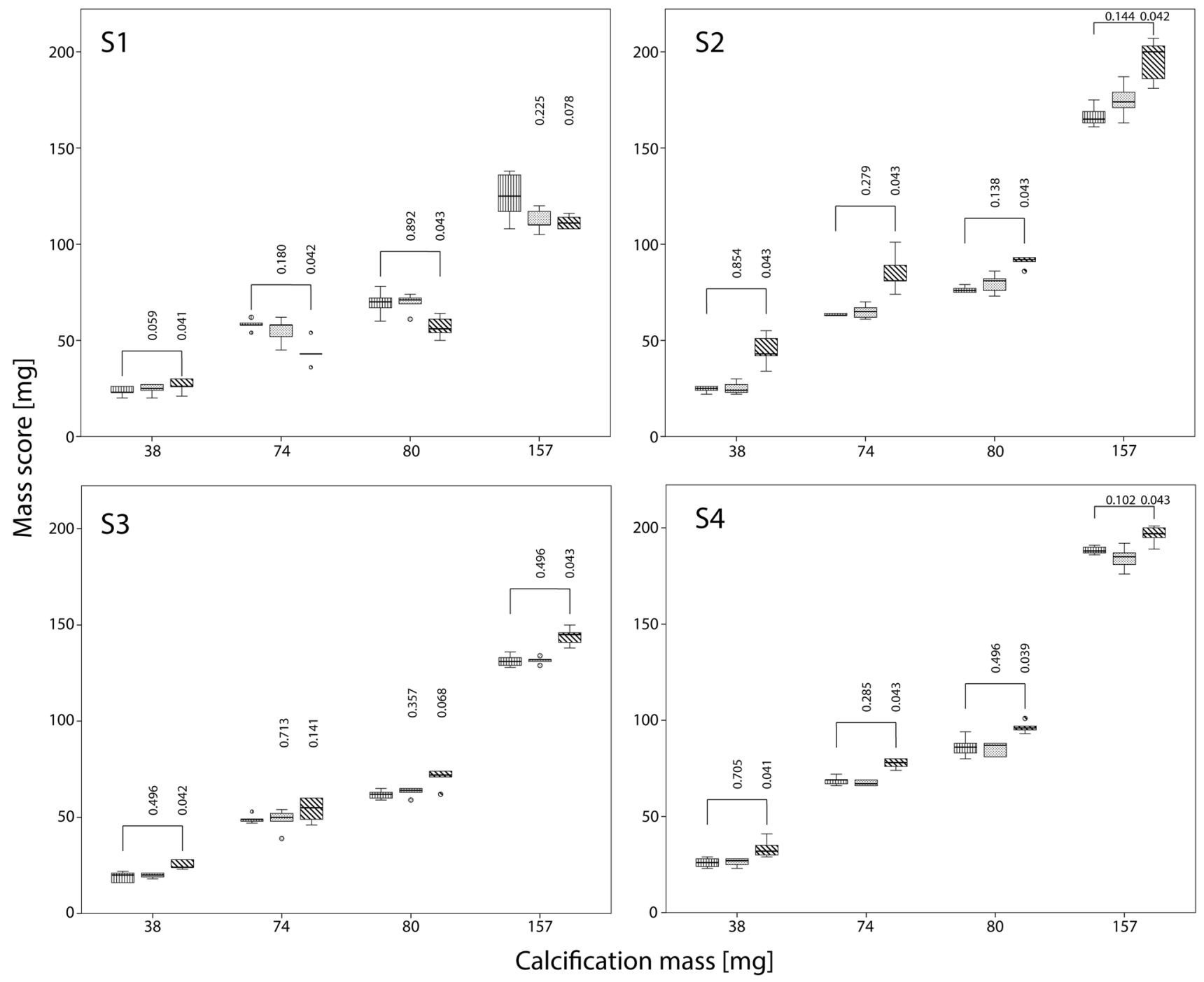

Fig. 4 Influence of dose reduction on mass score for S1-S4 with FBP. The movement of the calcification corresponds to displacements seen with heart rates of $60-75 \mathrm{bpm}$. For calcifications of $38,74,80$ and $157 \mathrm{mg}$ boxplots of the mass score at reference dose, and at 40

dynamic coronary calcium CT can result in a substantial increase in CCS, whereas the use of IR results in modestly decreased CCS. The most important clinically relevant finding is the ability to reduce dose by $40 \%$ in routinely used clinical protocols on state-of-the-art CT systems of four major manufacturers, without compromising the calcium score. This result is not only valid for high plaque burden, but also for the clinically more important mild to moderate coronary plaque burden, represented by the 38 and $74 \mathrm{mg}$ calcifications respectively.

Since risks of radiation dose increase with growing numbers of CT examinations, dose reduction techniques in CCS are highly relevant. Because new guidelines recommend CCS measurements if, after quantitative risk assessment, the risk-based treatment decision is uncertain, it is and $80 \%$ reduced dose are shown. Mass scores are compared with the mass score at reference dose using the Wilcoxon signed rank test. Significant different mass scores are indicated by brackets

expected that the number of CT examinations for CCS will further increase in coming years [5]. In the current study we found for all CT systems that dose reductions of $40 \%$, in combination with the in Table 2 specified reconstruction methods, did not significantly affect Agatston scores. For one vendor, the Agatston scores were even similar at $80 \%$ reduced dose, and for two vendors there was no significant difference in mass scores at $80 \%$ reduced dose in combination with IR.

These results are consistent with those of Hecht et al. [15] who showed in a patient study that for one CT system (equal to S2) CCS can be performed at reduced radiation dose $(50 \%)$ in combination with IR, without significantly affecting Agatston scores [15]. Ode et al. showed, for a pulsating phantom at $60 \mathrm{bpm}$ and one CT system (similar 


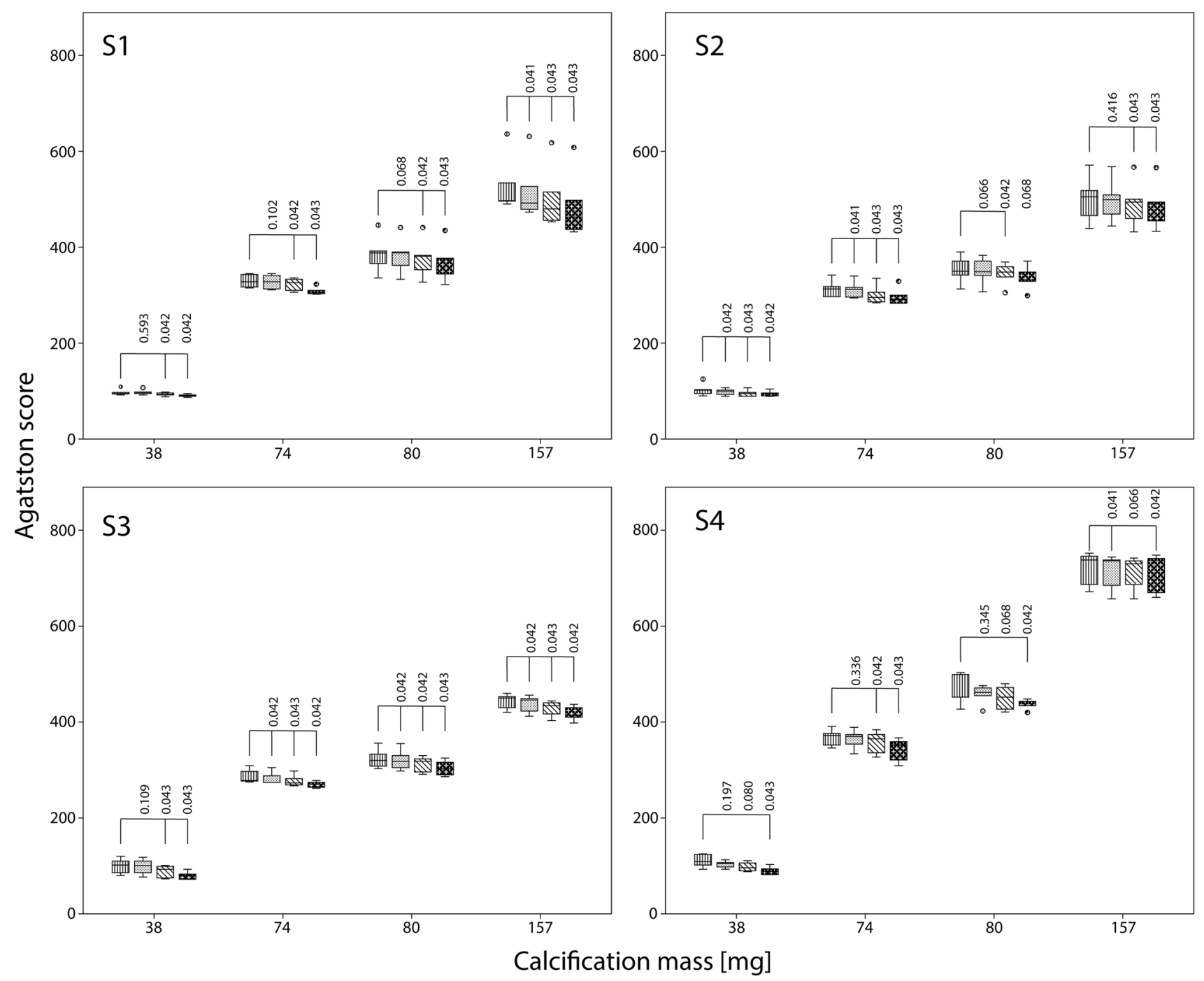

Fig. 5 Influence of IR on Agatston score for S1-S4 with FBP. The movement of the calcification corresponds to displacements seen with heart rates of 60-75 bpm. For calcifications of 38, 74, 80 and $157 \mathrm{mg}$ boxplots of the Agatston score at FBP and increasing levels of IR

to S4), that increased IR resulted in decreased Agatston scores, which is in agreement with our results [22]. In comparison with full dose FBP, Agatston scores were not influenced at IR levels L2 and L3 in combination with dose reduction up to $75 \%$, for all used calcifications combined. In our study however, Agatston scores at 40 and $80 \%$ reduced dose were found to be significantly different for all IR levels. The reason for this difference is that we only included combinations of dose reduction and IR, when valid for all calcifications separately. Our results also correspond well with a recent study which showed that IR has the potential to reduce radiation dose with $27-54 \%$ using a non-dynamic phantom and the same CT systems [23]. With non-dynamic ex vivo human hearts it was shown that a dose reduction of $80 \%$ was possible for the four CT systems [23, 24]. This (from left to right: L1, L2 and L3) are shown. Agatston scores are compared with the Agatston score at FBP using the Wilcoxon signed rank test. Significant different Agatston scores are indicated by brackets

study, however, used static calcifications, did not report on a reference standard of true calcification mass, and used a small-sized phantom. In our dynamic study, we found that a dose reduction of $80 \%$ was only feasible for one CT system, and a dose reduction of $40 \%$ was possible for all four CT systems, even for low-density calcifications in combination with specific reconstruction methods. Because iterative $\mathrm{CT}$ reconstruction significantly reduces calcium scores $[10,25]$, which potentially alters perceived cardiovascular risk [26], this effect may be counter balanced by the use of reduced dose levels. Moreover, it has been shown that the application of IR significantly improves objective image quality [12], and does not alter quantitative analysis of coronary plaque volume, composition and luminal area [27]. 


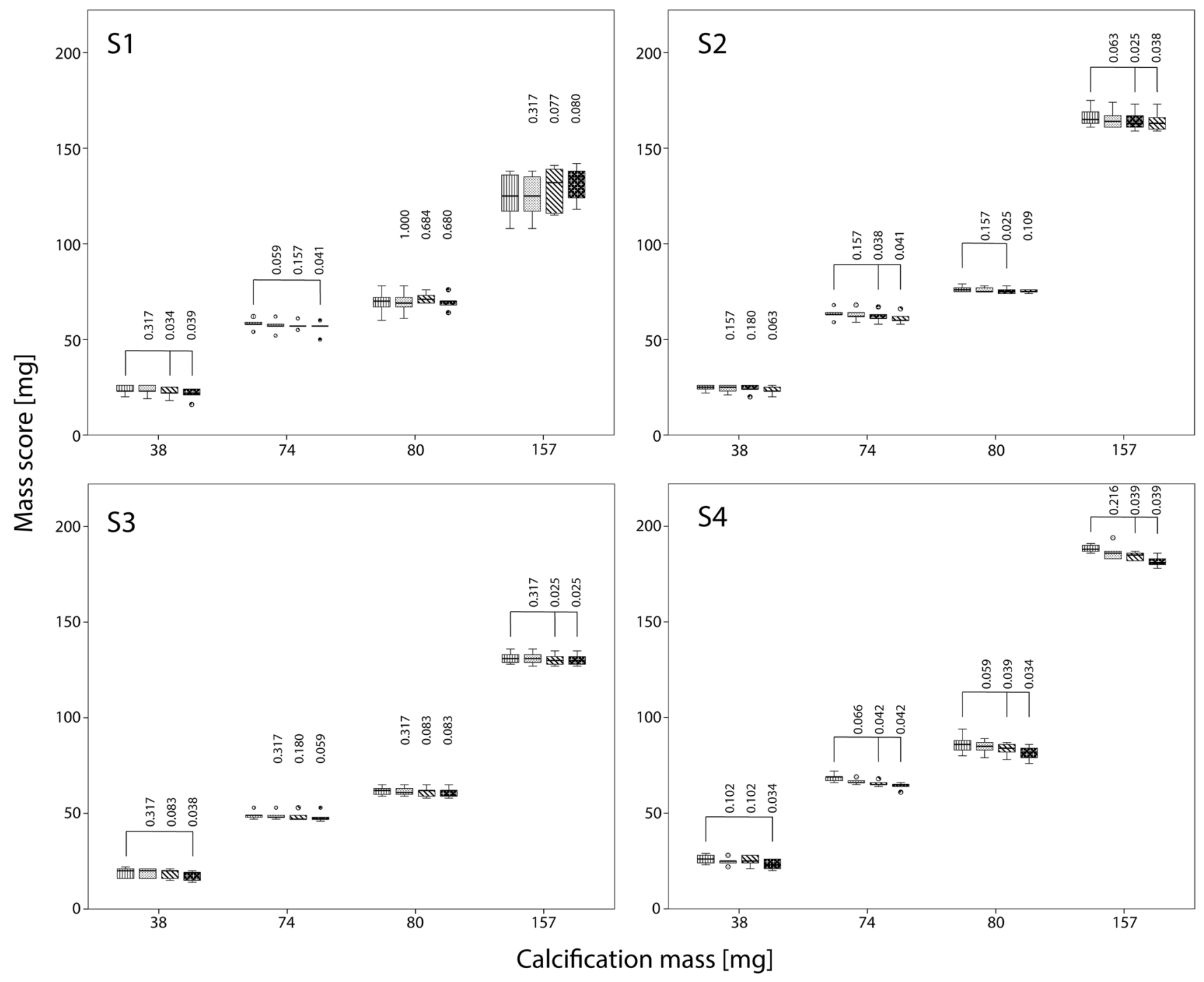

Fig. 6 Influence of IR on mass score for S1-S4 with FBP. The movement of the calcification corresponds to displacements seen with heart rates of 60-75 bpm. For calcifications of 38, 74, 80 and $157 \mathrm{mg}$ boxplots of the mass score at FBP and increasing levels of IR (from

Our results showed a relatively large variation in calcium scores between the CT systems, with Agatston scores ranging from 450 to 738 , for the $157 \mathrm{mg}$ calcification. This is in line with previous studies that found that state-of the-art CT scanners of different manufacturers produce substantially different Agatston scores, which can result in reclassification of patients to high- or low-risk categories in up to $6.5 \%$ of the cases [28]. Moreover, mass scores generally underestimated the physical mass of the inserts by 3-23\% depending on the specific CT system. Underestimations of the physical mass up to $68 \%$ were also observed with a static calcium phantom [29]. left to right: L1, L2 and L3) are shown. Mass scores are compared with the mass score at FBP using the Wilcoxon signed rank test. Significant different mass scores are indicated by brackets

Reference dose levels, from routinely used clinical protocols of the four high-end CT systems, showed large differences $(2.8-10.6 \mathrm{mGy})$. Despite of these differences in dose levels, similar noise levels were found (22-28 HU). It is important to note, however, that noise is not only determined by dose, but—among other parameters-also by reconstruction kernel. A sharper kernel results in more noise as compared to a softer kernel, if the dose levels are the same. Therefore, different CT acquisition and reconstruction settings may result in different dose levels but similar noise levels. The noise levels behaved as expected as a function of dose reduction and IR: noise levels 
Table 2 Reconstructions per CT system S1-S4 that did not result in significantly different Agatston and mass scores at $60-75 \mathrm{bpm}$ and at a dose reduction of 40 and $80 \%$ with respect to the FBP-reference dose

\begin{tabular}{llll}
\hline CT system & $\begin{array}{l}\text { Dose reduc- } \\
\text { tion }(\%)\end{array}$ & Agatston score & Mass scores \\
\hline S1 & 40 & L1 & FBP, L1 \\
& 80 & n/a & n/a \\
S2 & 40 & FBP, L1, L2, L3 & FBP, L1, L2, L3 \\
& 80 & L2, L3 & L1 \\
S3 & 40 & FBP, L1, L2 & FBP, L1, L2, L3 \\
& 80 & n/a & L2, L3 \\
S4 & 40 & FBP & FBP \\
& 80 & n/a & n/a \\
\hline
\end{tabular}

$F B P$ filtered back projection, $L 1, L 2, L 3$ increasing levels of iterative reconstruction

Table 3 Physical mass and corresponding mass scores for all CT systems and calcification masses

\begin{tabular}{lccc}
\hline CT system & $\begin{array}{l}\text { Physical } \\
\text { mass }(\mathrm{mg})\end{array}$ & Mass score $(\mathrm{mg})$ & Deviation $(\%)$ \\
\hline S1 & 38 & $23(20-26)$ & $-39(-47 ;-32)$ \\
& 74 & $58(54-62)$ & $-22(-27 ;-16)$ \\
& 80 & $70(60-78)$ & $-13(-25 ;-3)$ \\
& 157 & $125(108-138)$ & $-20(-31 ;-12)$ \\
S2 & 38 & $25(22-26)$ & $-33(-43 ;-31)$ \\
& 74 & $63(59-68)$ & $-15(-20 ;-8)$ \\
& 80 & $76(75-79)$ & $-5(-6 ;-1)$ \\
& 157 & $165(161-175)$ & $5(3 ; 11)$ \\
S3 & 38 & $20(16-22)$ & $-46(-57 ;-42)$ \\
& 74 & $49(47-53)$ & $-34(-37 ;-28)$ \\
& 80 & $62(59-65)$ & $-23(-26 ;-19)$ \\
& 157 & $131(128-136)$ & $-17(-19 ;-13)$ \\
S4 & 38 & $26(23-29)$ & $-31(-40 ;-24)$ \\
& 74 & $69(66-72)$ & $-7(-11 ;-3)$ \\
& 80 & $86(80-94)$ & $7(0 ; 18)$ \\
& 157 & $188(186-191)$ & $20(19 ; 21)$ \\
\hline
\end{tabular}

The mass scores are expressed as median and range

The difference between the median and physical mass is also given as median and range

increased at decreasing dose, and noise levels decreased at increased IR. Our findings indicate that even in the presence of comparable noise levels CCS differed up to $39 \%$ between different CT systems at full dose FBP. These differences are surprising for a relatively straightforward metric as the coronary calcium score.

This study has limitations. First, this was an in-vitro study with artificial arteries with calcified inserts. However, the inserts where embedded in an anthropomorphic phantom and were translated at a velocity that is generally observed in in-vivo studies, and the masses of the inserts were in range with calcium masses clinically detected in patients [30]. Second, movement of the calcifications was linear. In vivo, coronary arteries perform a complex movement in three dimensions, which was not feasible in our setup. However, because a linear movement can approximate the movement in 3D during the acquisition time of the $\mathrm{CT}$ data, we estimate that addition of $3 \mathrm{D}$ movement would result in minor changes in our results. Third, analysis on the inter and intra variability for the different CT systems has not been performed. The associated CT specific correlation between noise reduction and CCS accuracy was also not within the scope of this study. However, these analysis can answer questions about current practice. For example specificity, sensitivity, variations in CCS score between different vendors and the possibility to reduce dose without impact on the metric. Finally, only sequential scan modes were used. With the current appearance of high-pitch spiral mode scanning for coronary calcium it would be interesting to assess the differences in the accuracy of coronary calcium assessment between sequential and high-pitch spiral mode. However, that was not within the scope of this study.

We conclude that for all CT systems a dose reduction of $40 \%$ in combination with specific reconstruction gives a CCS comparable for reference protocols. For several systems, even higher dose reductions are possible. Dose reduction results in increased noise and consequently increased CCS, whereas increased IR results in decreased CCS. Mass scores generally underestimated physical mass of the calcifications.

\section{Compliance with ethical standards}

Conflict of interest The Radiology Department of the University Medical Center Utrecht received institutional grants from Philips Healthcare. Martin Willemink received personal fees for lectures from Philips Healthcare.

Open Access This article is distributed under the terms of the Creative Commons Attribution 4.0 International License (http:// creativecommons.org/licenses/by/4.0/), which permits unrestricted use, distribution, and reproduction in any medium, provided you give appropriate credit to the original author(s) and the source, provide a link to the Creative Commons license, and indicate if changes were made.

\section{Appendix 1}

See Tables 4 and 5. 
Table 4 Agatston scores (median and range) for all CT systems, calcification masses, reconstructions and dose values

\begin{tabular}{|c|c|c|c|c|c|c|c|c|}
\hline \multirow[t]{2}{*}{ CT system } & \multirow[t]{2}{*}{ Mass } & \multirow[t]{2}{*}{ Recon. } & \multicolumn{2}{|l|}{ Full dose } & \multicolumn{2}{|l|}{$40 \%$ reduction } & \multicolumn{2}{|l|}{$80 \%$ reduction } \\
\hline & & & Median (range) & $\mathrm{p}$ value & Median (range) & p-value & Median (range) & p-value \\
\hline \multirow[t]{16}{*}{$\mathrm{S} 1$} & \multirow[t]{4}{*}{$38 \mathrm{mg}$} & FBP & $\begin{array}{l}95 \\
(92-109)\end{array}$ & Ref & $\begin{array}{l}109 \\
(99-127)\end{array}$ & 0.041 & $\begin{array}{l}150 \\
(137-159)\end{array}$ & 0.043 \\
\hline & & L1 & $\begin{array}{l}97 \\
(92-107)\end{array}$ & 0.593 & $\begin{array}{l}96 \\
(93-108)\end{array}$ & 0.686 & $\begin{array}{l}139 \\
(133-147)\end{array}$ & 0.043 \\
\hline & & $\mathrm{L} 2$ & $\begin{array}{l}93 \\
(88-98)\end{array}$ & 0.042 & $\begin{array}{l}93 \\
(90-105)\end{array}$ & 0.141 & $\begin{array}{l}121 \\
(94-128)\end{array}$ & 0.225 \\
\hline & & L3 & $\begin{array}{l}91 \\
(87-95)\end{array}$ & 0.042 & $\begin{array}{l}91 \\
(88-95)\end{array}$ & 0.080 & $\begin{array}{l}94 \\
(88-107)\end{array}$ & 0.066 \\
\hline & \multirow[t]{4}{*}{$74 \mathrm{mg}$} & FBP & $\begin{array}{l}328 \\
(315-345)\end{array}$ & Ref & $\begin{array}{l}323 \\
(308-336)\end{array}$ & 0.042 & $\begin{array}{l}331 \\
(320-345)\end{array}$ & 0.684 \\
\hline & & L1 & $\begin{array}{l}328 \\
(311-345)\end{array}$ & 0.102 & $\begin{array}{l}318 \\
(308-337)\end{array}$ & 0.068 & $\begin{array}{l}325 \\
(319-332)\end{array}$ & 0.498 \\
\hline & & $\mathrm{L} 2$ & $\begin{array}{l}326 \\
(306-336)\end{array}$ & 0.042 & $\begin{array}{l}305 \\
(296-311)\end{array}$ & 0.043 & $\begin{array}{l}314 \\
(303-326)\end{array}$ & 0.225 \\
\hline & & L3 & $\begin{array}{l}305 \\
(302-323)\end{array}$ & 0.043 & $\begin{array}{l}302 \\
(294-307)\end{array}$ & 0.043 & $\begin{array}{l}306 \\
(299-311)\end{array}$ & 0.042 \\
\hline & \multirow[t]{4}{*}{$80 \mathrm{mg}$} & FBP & $\begin{array}{l}388 \\
(336-446)\end{array}$ & Ref & $\begin{array}{l}377 \\
(347-464)\end{array}$ & 0.893 & $\begin{array}{l}419 \\
(388-465)\end{array}$ & 0.043 \\
\hline & & L1 & $\begin{array}{l}388 \\
(333-441)\end{array}$ & 0.068 & $\begin{array}{l}376 \\
(329-459)\end{array}$ & 0.343 & $\begin{array}{l}409 \\
(381-459)\end{array}$ & 0.043 \\
\hline & & $\mathrm{L} 2$ & $\begin{array}{l}381 \\
(327-441)\end{array}$ & 0.042 & $\begin{array}{l}372 \\
(325-452)\end{array}$ & 0.078 & $\begin{array}{l}405 \\
(370-446)\end{array}$ & 0.046 \\
\hline & & L3 & $\begin{array}{l}375 \\
(322-435)\end{array}$ & 0.043 & $\begin{array}{l}362 \\
(317-445)\end{array}$ & 0.043 & $\begin{array}{l}398 \\
(366-433)\end{array}$ & 0.225 \\
\hline & \multirow[t]{4}{*}{$157 \mathrm{mg}$} & FBP & $\begin{array}{l}497 \\
(490-636)\end{array}$ & Ref & $\begin{array}{l}595 \\
(561-638)\end{array}$ & 0.043 & $\begin{array}{l}664 \\
(602-707)\end{array}$ & 0.080 \\
\hline & & L1 & $\begin{array}{l}492 \\
(473-631)\end{array}$ & 0.041 & $\begin{array}{l}586 \\
(559-623)\end{array}$ & 0.080 & $\begin{array}{l}644 \\
(591-692)\end{array}$ & 0.080 \\
\hline & & $\mathrm{L} 2$ & $\begin{array}{l}480 \\
(453-618)\end{array}$ & 0.043 & $\begin{array}{l}573 \\
(538-596)\end{array}$ & 0.138 & $\begin{array}{l}629 \\
(580-667)\end{array}$ & 0.080 \\
\hline & & L3 & $\begin{array}{l}463 \\
(432-608)\end{array}$ & 0.043 & $\begin{array}{l}569 \\
(528-584)\end{array}$ & 0.345 & $\begin{array}{l}616 \\
(566-646)\end{array}$ & 0.138 \\
\hline \multirow[t]{11}{*}{$\mathrm{S} 2$} & \multirow[t]{4}{*}{$38 \mathrm{mg}$} & FBP & $\begin{array}{l}102 \\
(90-125)\end{array}$ & Ref & $\begin{array}{l}106 \\
(89-144)\end{array}$ & 0.854 & $\begin{array}{l}265 \\
(202-331)\end{array}$ & 0.043 \\
\hline & & L1 & $\begin{array}{l}99 \\
(89-107)\end{array}$ & 0.042 & $\begin{array}{l}103 \\
(84-112)\end{array}$ & 0.686 & $\begin{array}{l}132 \\
(108-209)\end{array}$ & 0.043 \\
\hline & & L2 & $\begin{array}{l}95 \\
(89-107)\end{array}$ & 0.043 & $\begin{array}{l}96 \\
(82-111)\end{array}$ & 0.104 & $\begin{array}{l}124 \\
(84-205)\end{array}$ & 0.225 \\
\hline & & L3 & $\begin{array}{l}95 \\
(89-104)\end{array}$ & 0.042 & $\begin{array}{l}95 \\
(69-108)\end{array}$ & 0.080 & $\begin{array}{l}99 \\
(70-203)\end{array}$ & 0.893 \\
\hline & \multirow[t]{4}{*}{$74 \mathrm{mg}$} & FBP & $\begin{array}{l}313 \\
(297-342)\end{array}$ & Ref & $\begin{array}{l}336 \\
(306-351)\end{array}$ & 0.138 & $\begin{array}{l}411 \\
(382-514)\end{array}$ & 0.043 \\
\hline & & $\mathrm{L} 1$ & $\begin{array}{l}312 \\
(294-340)\end{array}$ & 0.041 & $\begin{array}{l}323 \\
(307-347)\end{array}$ & 0.225 & $\begin{array}{l}343 \\
(307-421)\end{array}$ & 0.043 \\
\hline & & $\mathrm{L} 2$ & $\begin{array}{l}295 \\
(284-335)\end{array}$ & 0.043 & $\begin{array}{l}317 \\
(297-344)\end{array}$ & 1.000 & $\begin{array}{l}315 \\
(294-364)\end{array}$ & 0.892 \\
\hline & & L3 & $\begin{array}{l}291 \\
(283-329)\end{array}$ & 0.043 & $\begin{array}{l}311 \\
(287-337)\end{array}$ & 0.785 & $\begin{array}{l}309 \\
(287-354)\end{array}$ & 0.893 \\
\hline & \multirow[t]{3}{*}{$80 \mathrm{mg}$} & FBP & $\begin{array}{l}350 \\
(313-390)\end{array}$ & Ref & $\begin{array}{l}374 \\
(331-425)\end{array}$ & 0.225 & $\begin{array}{l}448 \\
(438-456)\end{array}$ & 0.043 \\
\hline & & $\mathrm{L} 1$ & $\begin{array}{l}349 \\
(307-383)\end{array}$ & 0.066 & $\begin{array}{l}376 \\
(328-423)\end{array}$ & 0.225 & $\begin{array}{l}389 \\
(371-404)\end{array}$ & 0.043 \\
\hline & & L2 & $\begin{array}{l}348 \\
(305-369)\end{array}$ & 0.042 & $\begin{array}{l}368 \\
(322-412)\end{array}$ & 0.893 & $\begin{array}{l}361 \\
(346-373)\end{array}$ & 0.893 \\
\hline
\end{tabular}


Table 4 (continued)

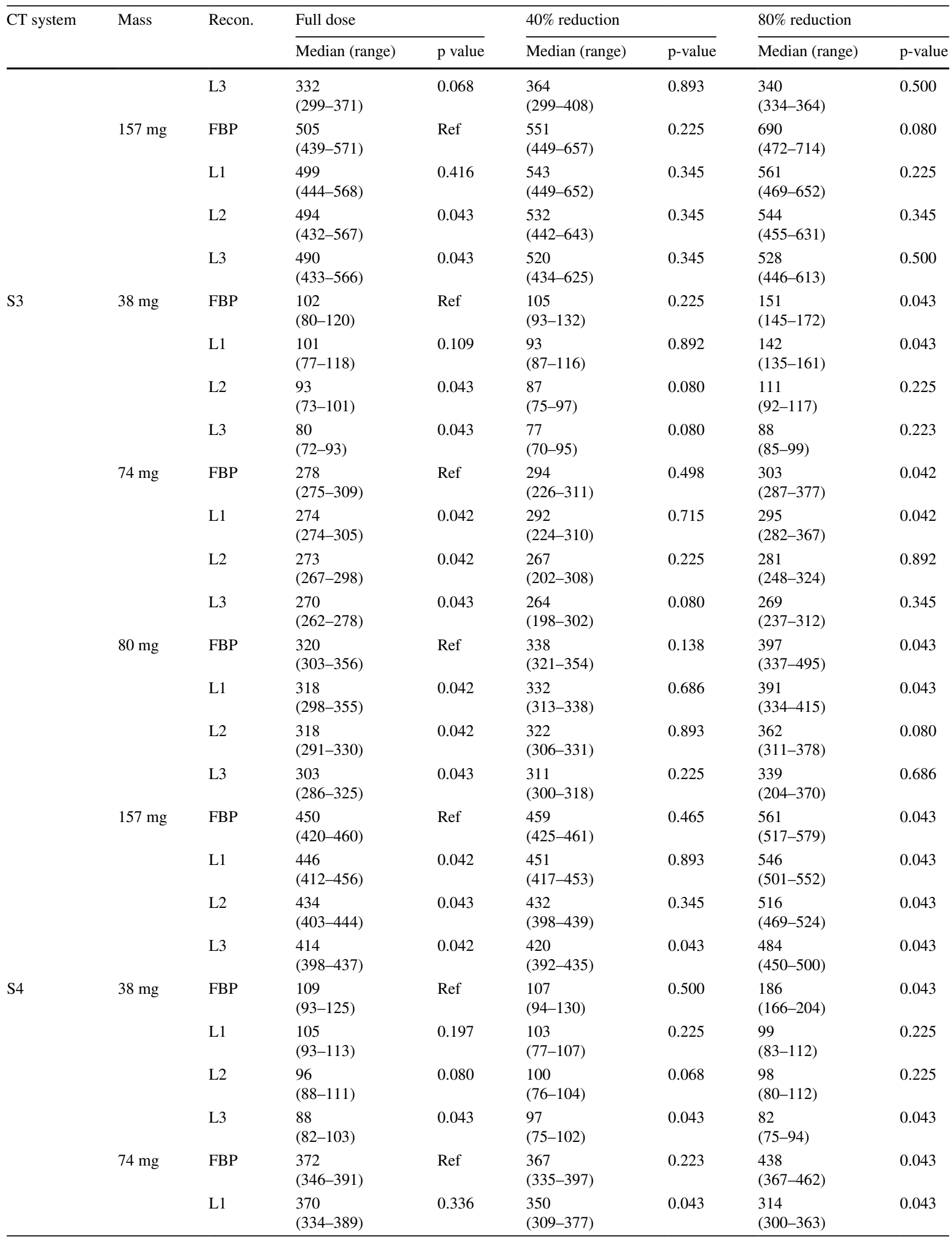


Table 4 (continued)

\begin{tabular}{|c|c|c|c|c|c|c|c|c|}
\hline \multirow[t]{2}{*}{ CT system } & \multirow[t]{2}{*}{ Mass } & \multirow[t]{2}{*}{ Recon. } & \multicolumn{2}{|l|}{ Full dose } & \multicolumn{2}{|l|}{$40 \%$ reduction } & \multicolumn{2}{|l|}{$80 \%$ reduction } \\
\hline & & & Median (range) & $\mathrm{p}$ value & Median (range) & p-value & Median (range) & p-value \\
\hline & & L2 & $\begin{array}{l}365 \\
(327-384)\end{array}$ & 0.042 & $\begin{array}{l}350 \\
(308-355)\end{array}$ & 0.042 & $\begin{array}{l}308 \\
(297-357)\end{array}$ & 0.043 \\
\hline & & L3 & $\begin{array}{l}352 \\
(309-367)\end{array}$ & 0.043 & $\begin{array}{l}344 \\
(298-350)\end{array}$ & 0.043 & $\begin{array}{l}296 \\
(293-314)\end{array}$ & 0.043 \\
\hline & $80 \mathrm{mg}$ & FBP & $\begin{array}{l}452 \\
(427-503)\end{array}$ & Ref & $\begin{array}{l}467 \\
(396-494)\end{array}$ & 0.225 & $\begin{array}{l}488 \\
(459-494)\end{array}$ & 0.892 \\
\hline & & $\mathrm{L} 1$ & $\begin{array}{l}462 \\
(423-476)\end{array}$ & 0.345 & $\begin{array}{l}445 \\
(392-453)\end{array}$ & 0.043 & $\begin{array}{l}402 \\
(370-438)\end{array}$ & 0.080 \\
\hline & & L2 & $\begin{array}{l}452 \\
(421-480)\end{array}$ & 0.068 & $\begin{array}{l}439 \\
(390-451)\end{array}$ & 0.043 & $\begin{array}{l}399 \\
(367-438)\end{array}$ & 0.080 \\
\hline & & L3 & $\begin{array}{l}438 \\
(420-448)\end{array}$ & 0.042 & $\begin{array}{l}411 \\
(390-446)\end{array}$ & 0.043 & $\begin{array}{l}370 \\
(349-425)\end{array}$ & 0.043 \\
\hline & $157 \mathrm{mg}$ & FBP & $\begin{array}{l}738 \\
(672-752)\end{array}$ & Ref & $\begin{array}{l}706 \\
(603-743)\end{array}$ & 0.078 & $\begin{array}{l}716 \\
(659-749)\end{array}$ & 0.500 \\
\hline & & L1 & $\begin{array}{l}736 \\
(657-744)\end{array}$ & 0.041 & $\begin{array}{l}698 \\
(597-726)\end{array}$ & 0.042 & $\begin{array}{l}666 \\
(585-675)\end{array}$ & 0.043 \\
\hline & & $\mathrm{L} 2$ & $\begin{array}{l}730 \\
(657-742)\end{array}$ & 0.066 & $\begin{array}{l}697 \\
(600-724)\end{array}$ & 0.043 & $\begin{array}{l}660 \\
(585-668)\end{array}$ & 0.042 \\
\hline & & L3 & $\begin{array}{l}736 \\
(660-748)\end{array}$ & 0.042 & $\begin{array}{l}694 \\
(606-725)\end{array}$ & 0.042 & $\begin{array}{l}654 \\
(584-661)\end{array}$ & 0.043 \\
\hline
\end{tabular}

$\mathrm{P}$ values of the Wilcoxon signed rank test are given for each combination of dose value and reconstruction type, compared to the reference FBP full dose value

Table 5 Mass scores (median and range) for all CT systems, calcification masses, reconstructions and dose values

\begin{tabular}{|c|c|c|c|c|c|c|c|c|}
\hline \multirow[t]{2}{*}{ CT system } & \multirow[t]{2}{*}{ Mass } & \multirow[t]{2}{*}{ Recon. } & \multicolumn{2}{|l|}{ Full dose } & \multicolumn{2}{|c|}{$40 \%$ reduction } & \multicolumn{2}{|c|}{$80 \%$ reduction } \\
\hline & & & $\begin{array}{l}\text { Median } \\
\text { (range) }\end{array}$ & $\mathrm{p}$ value & $\begin{array}{l}\text { Median } \\
\text { (range) }\end{array}$ & $\mathrm{p}$ value & $\begin{array}{l}\text { Median } \\
\text { (range) }\end{array}$ & $\mathrm{p}$ value \\
\hline \multirow[t]{12}{*}{ S1 } & \multirow[t]{4}{*}{$38 \mathrm{mg}$} & FBP & $\begin{array}{l}23 \\
(20-26)\end{array}$ & Ref & $\begin{array}{l}25 \\
(20-27)\end{array}$ & 0.059 & $\begin{array}{l}26 \\
(21-30)\end{array}$ & 0.041 \\
\hline & & L1 & $\begin{array}{l}23 \\
(19-26)\end{array}$ & 0.317 & $\begin{array}{l}24 \\
(21-26)\end{array}$ & 0.157 & $\begin{array}{l}28 \\
(25-29)\end{array}$ & 0.041 \\
\hline & & L2 & $\begin{array}{l}22 \\
(18-25)\end{array}$ & 0.034 & $\begin{array}{l}23 \\
(19-25)\end{array}$ & 0.043 & $\begin{array}{l}27 \\
(24-27)\end{array}$ & 0.038 \\
\hline & & L3 & $\begin{array}{l}22 \\
(16-24)\end{array}$ & 0.039 & $\begin{array}{l}22 \\
(16-24)\end{array}$ & 0.039 & $\begin{array}{l}26 \\
(21-26)\end{array}$ & 0.414 \\
\hline & \multirow[t]{4}{*}{$74 \mathrm{mg}$} & FBP & $\begin{array}{l}58 \\
(54-62)\end{array}$ & Ref & $\begin{array}{l}58 \\
(45-62)\end{array}$ & 0.180 & $\begin{array}{l}43 \\
(36-54)\end{array}$ & 0.042 \\
\hline & & L1 & $\begin{array}{l}57 \\
(52-62)\end{array}$ & 0.059 & $\begin{array}{l}58 \\
(52-62)\end{array}$ & 0.180 & $\begin{array}{l}48 \\
(44-58)\end{array}$ & 0.039 \\
\hline & & L2 & $\begin{array}{l}57 \\
(55-61)\end{array}$ & 0.157 & $\begin{array}{l}58 \\
(52-61)\end{array}$ & 0.109 & $\begin{array}{l}53 \\
(50-59)\end{array}$ & 0.039 \\
\hline & & L3 & $\begin{array}{l}57 \\
(50-60)\end{array}$ & 0.041 & $\begin{array}{l}57 \\
(53-60)\end{array}$ & 0.038 & $\begin{array}{l}58 \\
(50-58)\end{array}$ & 0.043 \\
\hline & \multirow[t]{4}{*}{$80 \mathrm{mg}$} & FBP & $\begin{array}{l}70 \\
(60-78)\end{array}$ & Ref & $\begin{array}{l}71 \\
(61-74)\end{array}$ & 0.892 & $\begin{array}{l}56 \\
(50-64)\end{array}$ & 0.043 \\
\hline & & L1 & $\begin{array}{l}69 \\
(61-78)\end{array}$ & 1.000 & $\begin{array}{l}70 \\
(65-74)\end{array}$ & 1.000 & $\begin{array}{l}58 \\
(51-66)\end{array}$ & 0.042 \\
\hline & & L2 & $\begin{array}{l}71 \\
(69-76)\end{array}$ & 0.684 & $\begin{array}{l}69 \\
(65-74)\end{array}$ & 0.893 & $\begin{array}{l}67 \\
(64-72)\end{array}$ & 0.414 \\
\hline & & L3 & $\begin{array}{l}70 \\
(64-76)\end{array}$ & 0.680 & $\begin{array}{l}70 \\
(66-73)\end{array}$ & 1.000 & $\begin{array}{l}69 \\
(62-73)\end{array}$ & 0.785 \\
\hline
\end{tabular}


Table 5 (continued)

\begin{tabular}{|c|c|c|c|c|c|c|c|c|}
\hline \multirow[t]{2}{*}{ CT system } & \multirow[t]{2}{*}{ Mass } & \multirow[t]{2}{*}{ Recon. } & \multicolumn{2}{|l|}{ Full dose } & \multicolumn{2}{|c|}{$40 \%$ reduction } & \multicolumn{2}{|c|}{$80 \%$ reduction } \\
\hline & & & $\begin{array}{l}\text { Median } \\
\text { (range) }\end{array}$ & $\mathrm{p}$ value & $\begin{array}{l}\text { Median } \\
\text { (range) }\end{array}$ & $\mathrm{p}$ value & $\begin{array}{l}\text { Median } \\
\text { (range) }\end{array}$ & $\mathrm{p}$ value \\
\hline & $157 \mathrm{mg}$ & FBP & $\begin{array}{l}125 \\
(108-138)\end{array}$ & Ref & $\begin{array}{l}110 \\
(105-120)\end{array}$ & 0.225 & $\begin{array}{l}111 \\
(108-116)\end{array}$ & 0.078 \\
\hline & & L1 & $\begin{array}{l}125 \\
(108-138)\end{array}$ & 0.317 & $\begin{array}{l}113 \\
(108-118)\end{array}$ & 0.223 & $\begin{array}{l}110 \\
(107-116)\end{array}$ & 0.080 \\
\hline & & $\mathrm{L} 2$ & $\begin{array}{l}132 \\
(115-141)\end{array}$ & 0.077 & $\begin{array}{l}112 \\
(104-122)\end{array}$ & 0.225 & $\begin{array}{l}111 \\
(105-114)\end{array}$ & 0.080 \\
\hline & & L3 & $\begin{array}{l}135 \\
(118-142)\end{array}$ & 0.080 & $\begin{array}{l}119 \\
(112-124)\end{array}$ & 0.225 & $\begin{array}{l}112 \\
(111-127)\end{array}$ & 0.225 \\
\hline \multirow[t]{16}{*}{$\mathrm{S} 2$} & $38 \mathrm{mg}$ & FBP & $\begin{array}{l}25 \\
(22-26)\end{array}$ & Ref & $\begin{array}{l}24 \\
(22-30)\end{array}$ & 0.854 & $\begin{array}{l}43 \\
(34-55)\end{array}$ & 0.043 \\
\hline & & L1 & $\begin{array}{l}25 \\
(21-26)\end{array}$ & 0.157 & $\begin{array}{l}23 \\
(21-28)\end{array}$ & 0.465 & $\begin{array}{l}28 \\
(21-38)\end{array}$ & 0.225 \\
\hline & & L2 & $\begin{array}{l}24 \\
(20-26)\end{array}$ & 0.180 & $\begin{array}{l}22 \\
(19-27)\end{array}$ & 0.257 & $\begin{array}{l}25 \\
(19-37)\end{array}$ & 0.500 \\
\hline & & L3 & $\begin{array}{l}23 \\
(20-26)\end{array}$ & 0.063 & $\begin{array}{l}22 \\
(18-27)\end{array}$ & 0.176 & $\begin{array}{l}24 \\
(17-37)\end{array}$ & 0.581 \\
\hline & $74 \mathrm{mg}$ & FBP & $\begin{array}{l}63 \\
(59-68)\end{array}$ & Ref & $65(61-70)$ & 0.279 & $\begin{array}{l}81 \\
(74-101)\end{array}$ & 0.043 \\
\hline & & L1 & $\begin{array}{l}62 \\
(59-68)\end{array}$ & 0.157 & $\begin{array}{l}64 \\
(59-69)\end{array}$ & 0.892 & $\begin{array}{l}64 \\
(61-80)\end{array}$ & 0.684 \\
\hline & & L2 & $\begin{array}{l}61 \\
(58-67)\end{array}$ & 0.038 & $\begin{array}{l}63 \\
(58-68)\end{array}$ & 0.414 & $\begin{array}{l}60 \\
(58-79)\end{array}$ & 0.893 \\
\hline & & L3 & $\begin{array}{l}60 \\
(58-66)\end{array}$ & 0.041 & $\begin{array}{l}62 \\
(58-67)\end{array}$ & 0.221 & $\begin{array}{l}60 \\
(57-77)\end{array}$ & 1.000 \\
\hline & $80 \mathrm{mg}$ & FBP & $\begin{array}{l}76 \\
(75-79)\end{array}$ & Ref & $\begin{array}{l}81 \\
(73-86)\end{array}$ & 0.138 & $\begin{array}{l}92 \\
(86-93)\end{array}$ & 0.043 \\
\hline & & L1 & $\begin{array}{l}75 \\
(75-78)\end{array}$ & 0.157 & $\begin{array}{l}80 \\
(72-85)\end{array}$ & 0.279 & $\begin{array}{l}76 \\
(71-78)\end{array}$ & 0.276 \\
\hline & & L2 & $\begin{array}{l}75 \\
(74-78)\end{array}$ & 0.025 & $\begin{array}{l}79 \\
(70-84)\end{array}$ & 0.683 & $\begin{array}{l}72 \\
(68-74)\end{array}$ & 0.042 \\
\hline & & L3 & $\begin{array}{l}75 \\
(74-76)\end{array}$ & 0.109 & $\begin{array}{l}78 \\
(70-83)\end{array}$ & 1.000 & $\begin{array}{l}71 \\
(66-73)\end{array}$ & 0.042 \\
\hline & $157 \mathrm{mg}$ & FBP & $\begin{array}{l}165 \\
(161-175)\end{array}$ & Ref & $\begin{array}{l}174 \\
(163-187)\end{array}$ & 0.144 & $\begin{array}{l}200 \\
(181-207)\end{array}$ & 0.042 \\
\hline & & L1 & $\begin{array}{l}164 \\
(161-174)\end{array}$ & 0.063 & $\begin{array}{l}170 \\
(161-186)\end{array}$ & 0.225 & $\begin{array}{l}164 \\
(162-188)\end{array}$ & 0.336 \\
\hline & & $\mathrm{L} 2$ & $\begin{array}{l}163 \\
(159-173)\end{array}$ & 0.025 & $\begin{array}{l}169 \\
(160-184)\end{array}$ & 0.498 & $\begin{array}{l}161 \\
(159-185)\end{array}$ & 0.498 \\
\hline & & L3 & $\begin{array}{l}163 \\
(159-173)\end{array}$ & 0.038 & $\begin{array}{l}168 \\
(159-182)\end{array}$ & 0.498 & $\begin{array}{l}160 \\
(157-183)\end{array}$ & 0.345 \\
\hline \multirow[t]{7}{*}{ S3 } & $38 \mathrm{mg}$ & FBP & $\begin{array}{l}20 \\
(16-22)\end{array}$ & Ref & $\begin{array}{l}20 \\
(18-21)\end{array}$ & 0.496 & $\begin{array}{l}24 \\
(23-28)\end{array}$ & 0.042 \\
\hline & & L1 & $\begin{array}{l}20 \\
(16-21)\end{array}$ & 0.317 & $\begin{array}{l}19 \\
(17-20)\end{array}$ & 0.854 & $\begin{array}{l}23 \\
(22-25)\end{array}$ & 0.042 \\
\hline & & $\mathrm{L} 2$ & $\begin{array}{l}20 \\
(15-21)\end{array}$ & 0.083 & $\begin{array}{l}18 \\
(16-19)\end{array}$ & 0.197 & $\begin{array}{l}20 \\
(19-20)\end{array}$ & 0.684 \\
\hline & & L3 & $\begin{array}{l}19 \\
(14-20)\end{array}$ & 0.038 & $\begin{array}{l}17 \\
(15-18)\end{array}$ & 0.104 & $\begin{array}{l}17 \\
(16-18)\end{array}$ & 0.225 \\
\hline & $74 \mathrm{mg}$ & FBP & $\begin{array}{l}49 \\
(47-53)\end{array}$ & Ref & $\begin{array}{l}50 \\
(39-54)\end{array}$ & 0.713 & $\begin{array}{l}55 \\
(46-60)\end{array}$ & 0.141 \\
\hline & & L1 & $\begin{array}{l}48 \\
(47-53)\end{array}$ & 0.317 & $\begin{array}{l}50 \\
(38-53)\end{array}$ & 1.000 & $\begin{array}{l}54 \\
(44-59)\end{array}$ & 0.225 \\
\hline & & L2 & $\begin{array}{l}47 \\
(47-53)\end{array}$ & 0.180 & $\begin{array}{l}49 \\
(38-53)\end{array}$ & 0.414 & $\begin{array}{l}50 \\
(42-55)\end{array}$ & 1.000 \\
\hline
\end{tabular}


Table 5 (continued)

\begin{tabular}{|c|c|c|c|c|c|c|c|c|}
\hline \multirow[t]{2}{*}{ CT system } & \multirow[t]{2}{*}{ Mass } & \multirow[t]{2}{*}{ Recon. } & \multicolumn{2}{|l|}{ Full dose } & \multicolumn{2}{|c|}{$40 \%$ reduction } & \multicolumn{2}{|c|}{$80 \%$ reduction } \\
\hline & & & $\begin{array}{l}\text { Median } \\
\text { (range) }\end{array}$ & $\mathrm{p}$ value & $\begin{array}{l}\text { Median } \\
\text { (range) }\end{array}$ & $\mathrm{p}$ value & $\begin{array}{l}\text { Median } \\
\text { (range) }\end{array}$ & $\mathrm{p}$ value \\
\hline & & L3 & $\begin{array}{l}47 \\
(46-53)\end{array}$ & 0.059 & $\begin{array}{l}48 \\
(37-52)\end{array}$ & 0.131 & $\begin{array}{l}46 \\
(39-52)\end{array}$ & 0.176 \\
\hline & $80 \mathrm{mg}$ & FBP & $\begin{array}{l}62 \\
(59-65)\end{array}$ & Ref & $\begin{array}{l}64 \\
(59-65)\end{array}$ & 0.357 & $\begin{array}{l}72 \\
(62-93)\end{array}$ & 0.068 \\
\hline & & L1 & $\begin{array}{l}61 \\
(59-65)\end{array}$ & 0.317 & $\begin{array}{l}63 \\
(59-65)\end{array}$ & 0.416 & $\begin{array}{l}71 \\
(61-78)\end{array}$ & 0.080 \\
\hline & & L2 & $\begin{array}{l}62 \\
(58-65)\end{array}$ & 0.083 & $\begin{array}{l}62 \\
(58-64)\end{array}$ & 1.000 & $\begin{array}{l}66 \\
(58-70)\end{array}$ & 0.176 \\
\hline & & L3 & $\begin{array}{l}62 \\
(58-65)\end{array}$ & 0.083 & $\begin{array}{l}62 \\
(57-64)\end{array}$ & 0.892 & $\begin{array}{l}64 \\
(56-65)\end{array}$ & 0.713 \\
\hline & $157 \mathrm{mg}$ & FBP & $\begin{array}{l}131 \\
(128-136)\end{array}$ & Ref & $\begin{array}{l}132 \\
(129-134)\end{array}$ & 0.496 & $\begin{array}{l}145 \\
(138-150)\end{array}$ & 0.043 \\
\hline & & L1 & $\begin{array}{l}131 \\
(127-136)\end{array}$ & 0.317 & $\begin{array}{l}131 \\
(128-133)\end{array}$ & 1.000 & $\begin{array}{l}139 \\
(135-146)\end{array}$ & 0.043 \\
\hline & & L2 & $\begin{array}{l}130 \\
(127-135)\end{array}$ & 0.025 & $\begin{array}{l}130 \\
(127-132)\end{array}$ & 0.680 & $\begin{array}{l}133 \\
(131-141)\end{array}$ & 0.273 \\
\hline & & L3 & $\begin{array}{l}130 \\
(127-135)\end{array}$ & 0.025 & $\begin{array}{l}130 \\
(126-132)\end{array}$ & 0.257 & $\begin{array}{l}130 \\
(126-137)\end{array}$ & 0.854 \\
\hline \multirow[t]{16}{*}{ S4 } & $38 \mathrm{mg}$ & FBP & $\begin{array}{l}26 \\
(23-29)\end{array}$ & Ref & $\begin{array}{l}27 \\
(23-28)\end{array}$ & 0.705 & $\begin{array}{l}32 \\
(29-41)\end{array}$ & 0.041 \\
\hline & & $\mathrm{L} 1$ & $\begin{array}{l}25 \\
(22-28)\end{array}$ & 0.102 & $\begin{array}{l}26 \\
(21-27)\end{array}$ & 0.102 & $\begin{array}{l}23 \\
(19-27)\end{array}$ & 0.066 \\
\hline & & L2 & $\begin{array}{l}25 \\
(21-28)\end{array}$ & 0.102 & $\begin{array}{l}25 \\
(20-26)\end{array}$ & 0.068 & $\begin{array}{l}23 \\
(18-24)\end{array}$ & 0.068 \\
\hline & & L3 & $\begin{array}{l}23 \\
(20-26)\end{array}$ & 0.034 & $\begin{array}{l}24 \\
(20-27)\end{array}$ & 0.042 & $\begin{array}{l}21 \\
(17-25)\end{array}$ & 0.043 \\
\hline & $74 \mathrm{mg}$ & FBP & $\begin{array}{l}69 \\
(66-72)\end{array}$ & Ref & $\begin{array}{l}67 \\
(66-69)\end{array}$ & 0.285 & $\begin{array}{l}78 \\
(74-80)\end{array}$ & 0.043 \\
\hline & & L1 & $\begin{array}{l}66 \\
(65-69)\end{array}$ & 0.066 & $\begin{array}{l}64 \\
(61-66)\end{array}$ & 0.042 & $\begin{array}{l}62 \\
(60-66)\end{array}$ & 0.042 \\
\hline & & L2 & $\begin{array}{l}65 \\
(64-68)\end{array}$ & 0.042 & $\begin{array}{l}64 \\
(61-67)\end{array}$ & 0.039 & $\begin{array}{l}60 \\
(59-61)\end{array}$ & 0.043 \\
\hline & & L3 & $\begin{array}{l}65 \\
(61-66)\end{array}$ & 0.042 & $\begin{array}{l}62 \\
(59-65)\end{array}$ & 0.043 & $\begin{array}{l}59 \\
(56-62)\end{array}$ & 0.042 \\
\hline & $80 \mathrm{mg}$ & FBP & $\begin{array}{l}86 \\
(80-94)\end{array}$ & Ref & $\begin{array}{l}87 \\
(81-88)\end{array}$ & 0.496 & $\begin{array}{l}96 \\
(93-101)\end{array}$ & 0.039 \\
\hline & & L1 & $\begin{array}{l}85 \\
(79-89)\end{array}$ & 0.059 & $\begin{array}{l}82 \\
(76-88)\end{array}$ & 0.042 & $\begin{array}{l}79 \\
(76-79)\end{array}$ & 0.043 \\
\hline & & $\mathrm{L} 2$ & $\begin{array}{l}84 \\
(78-87)\end{array}$ & 0.039 & $\begin{array}{l}81 \\
(76-85)\end{array}$ & 0.041 & $\begin{array}{l}78 \\
(75-80)\end{array}$ & 0.043 \\
\hline & & L3 & $\begin{array}{l}82 \\
(76-86)\end{array}$ & 0.034 & $\begin{array}{l}79 \\
(74-84)\end{array}$ & 0.042 & $\begin{array}{l}74 \\
(72-80)\end{array}$ & 0.042 \\
\hline & $157 \mathrm{mg}$ & FBP & $\begin{array}{l}188 \\
(186-191)\end{array}$ & Ref & $\begin{array}{l}185 \\
(176-192)\end{array}$ & 0.102 & $\begin{array}{l}197 \\
(189-201)\end{array}$ & 0.043 \\
\hline & & L1 & $\begin{array}{l}186 \\
(183-194)\end{array}$ & 0.216 & $\begin{array}{l}179 \\
(169-186)\end{array}$ & 0.043 & $\begin{array}{l}168 \\
(167-173)\end{array}$ & 0.042 \\
\hline & & L2 & $\begin{array}{l}185 \\
(182-187)\end{array}$ & 0.039 & $\begin{array}{l}178 \\
(169-183)\end{array}$ & 0.043 & $\begin{array}{l}166 \\
(165-171)\end{array}$ & 0.042 \\
\hline & & L3 & $\begin{array}{l}181 \\
(178-186)\end{array}$ & 0.039 & $\begin{array}{l}175 \\
(168-179)\end{array}$ & 0.041 & $\begin{array}{l}162 \\
(160-168)\end{array}$ & 0.043 \\
\hline
\end{tabular}

$\mathrm{P}$ values of the Wilcoxon signed rank test are given for each combination of dose value and reconstruction type, compared to the reference FBP full dose value 


\section{Appendix 2}

See Fig. 7.

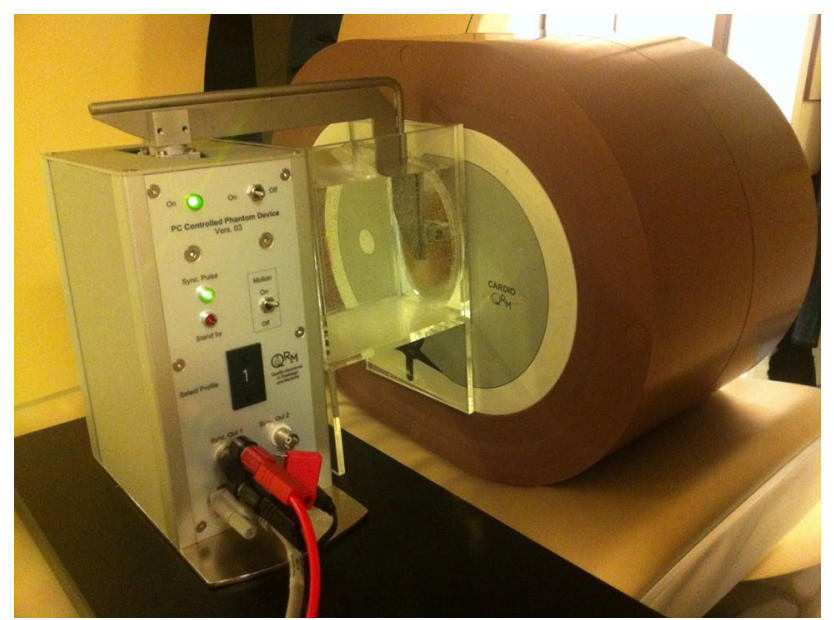

Fig. 7 Anthropomorphic chest phantom with extension ring and motion controller (QRM, Moehrendorf, Germany). An artificial coronary artery moved in the horizontal plane inside the water tank in the center of the chest phantom

\section{Appendix 3}

See Fig. 8.

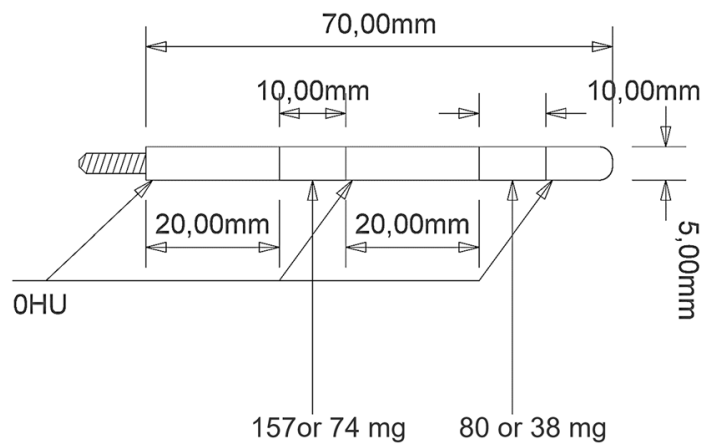

Fig. 8 The cylindrical artificial coronary artery contained two calcified inserts with a diameter of $5.0 \pm 0.1 \mathrm{~mm}$ and a length of $10.0 \pm 0.1 \mathrm{~mm}$ as indicated

\section{References}

1. Agatston AS, Janowitz WR, Hildner FJ et al (1990) Quantification of coronary artery calcium using ultrafast computed tomography. J Am Coll Cardiol 15:827-832

2. Versteylen MO, Joosen IA, Winkens MH et al (2013) Combined use of exercise electrocardiography, coronary calcium score and cardiac CT angiography for the prediction of major cardiovascular events in patients presenting with stable chest pain. Int J Cardiol 167:121-125. doi:10.1016/j. ijcard.2011.12.016

3. Brenner DJ, Hall EJ (2007) Current concepts—computed tomography-an increasing source of radiation exposure. N Engl J Med 357:2277-2284. doi:10.1056/NEJMra072149

4. De González AB, Darby S (2004) Risk of cancer from diagnostic X-rays: estimates for the UK and 14 other countries. Lancet 363:345-351. doi:10.1016/S0140-6736(04)15433-0

5. Goff DC, Lloyd-Jones DM, Bennett G et al (2014) 2013 ACC/ AHA guideline on the assessment of cardiovascular risk: a report of the American college of cardiology/American heart association task force on practice guidelines. Circulation 129:49-76. doi:10.1161/01.cir.0000437741.48606.98

6. Leipsic J, LaBounty TM, Heilbron B et al (2010) Estimated radiation dose reduction using adaptive statistical iterative reconstruction in coronary CT angiography: the ERASIR study. Am J Roentgenol 195:655-660. doi:10.2214/AJR.10.4288

7. Moscariello A, Takx R, Schoepf U (2011) Coronary CT angiography: image quality, diagnostic accuracy, and potential for radiation dose reduction using a novel iterative image reconstruction technique-comparison with traditional filtered back projection. Eur Radiol 21:2130-2138. doi:10.1007/s00330-011-2164-9

8. Sato J, Akahane M, Inano S et al (2012) Effect of radiation dose and adaptive statistical iterative reconstruction on image quality of pulmonary computed tomography. Jpn. J Radiol 30:146-153. doi:10.1007/s11604-011-0026-7

9. Fleischmann D, Boas FE (2011) Computed tomography-old ideas and new technology. Eur Radiol 21:510-517. doi:10.1007/ s00330-011-2056-Z

10. Gebhard C, Fiechter M, Fuchs TA et al (2013) Coronary artery calcium scoring: influence of adaptive statistical iterative reconstruction using 64-MDCT. Int J Cardiol 167:2932-2937. doi:10.1016/j.ijcard.2012.08.003

11. Willemink MJ, Takx RAP, De Jong PA et al (2014) The impact of $\mathrm{CT}$ radiation dose reduction and iterative reconstruction algorithms from four different vendors on coronary calcium scoring. Eur Radiol 24:2201-2212. doi:10.1007/s00330-014-3217-7

12. Willemink MJ, De Jong PA, Leiner $T$ et al (2013) Iterative reconstruction techniques for computed tomography Part 1: technical principles. Eur Radiol 23:1623-1631. doi:10.1007/ s00330-012-2765-y

13. Schindler A, Vliegenthart R, Schoepf UJ et al (2014) Iterative image reconstruction techniques for CT coronary artery calcium quantification: comparison with traditional filtered back projection in vitro and in vivo. Radiology 270:387-393. doi:10.1148/ radiol.13130233

14. Takahashi M, Kimura F, Umezawa T et al (2016) Comparison of adaptive statistical iterative and filtered back projection reconstruction techniques in quantifying coronary calcium. J Cardiovasc Comput Tomogr 10:61-68. doi:10.1016/j.jcct.2015.07.012

15. Hecht HS, De Siqueira MEM, Cham M et al (2015) Low-vs. Standard-dose coronary artery calcium scanning. Eur Heart $\mathbf{J}$ Cardiovasc Imaging 16:358-363. doi:10.1093/ehjci/jeu218

16. Greuter MJW, Groen JM, Nicolai LJ et al (2009) A model for quantitative correction of coronary calcium scores on multidetector, dual source, and electron beam computed tomography for influences of linear motion, calcification density, and temporal resolution: a cardiac phantom study. Med Phys 36:5079-5088. doi:10.1118/1.3213536

17. Groen JM, Greuter MJW, Vliegenthart R et al (2008) Calcium scoring using 64-slice MDCT, dual source CT and EBT: a comparative phantom study. Int J Cardiovasc Imaging 24:547-556. doi:10.1007/s10554-007-9282-0 
18. Groen JM, Dijkstra H, Greuter MJW, Oudkerk M (2009) Threshold adjusted calcium scoring using CT is less susceptible to cardiac motion and more accurate. Med Phys 36:438. doi: $10.1118 / 1.3049590$

19. McCollough CH, Ulzheimer S, Halliburton SS et al (2007) Coronary artery calcium: a multi-institutional, multimanufacturer international standard for quantification at cardiac CT. Radiology 243:527-538. doi:10.1148/radiol.2432050808

20. Achenbach S, Ropers D, Holle J et al (2000) In-plane coronary arterial motion velocity: measurement with electron-beam CT1. Radiology 216:457-463. doi:10.1148/radiology.216.2.r0 Oau19457

21. Husmann L, Leschka S, Desbiolles L et al (2007) Coronary artery motion and cardiac phases: dependency on heart rateimplications for CT image reconstruction. Radiology 245:567576. doi:10.1148/radiol.2451061791

22. Ode S, Kobayashi Y, Nozu Y, Ogawa Y (2016) The impact of iterative reconstruction on reducing the radiation dose for coronary calcium scoring: an investigation using pulsating calcified coronary phantom. J St. Marianna Univ 7:95-103

23. Willemink MJ, Takx RA, de Jong PA et al (2014) Computed tomography radiation dose reduction: Effect of different iterative reconstruction algorithms on image quality. J Comput Assist Tomogr 38:815-823. doi:10.1097/RCT.0000000000000128

24. Den Harder AM, Willemink MJ, Bleys RLAW et al (2014) Dose reduction for coronary calcium scoring with hybrid and model-based iterative reconstruction: An ex vivo study. Int J Cardiovasc Imaging 30:1125-1133. doi:10.1007/s10554-014-0434-8

25. Van Osch JAC, Mouden M, Van Dalen JA et al (2014) Influence of iterative image reconstruction on CT-based calcium score measurements. Int $\mathbf{J}$ Cardiovasc Imaging 30:961-967. doi:10.1007/s10554-014-0409-9

26. Kurata A, Dharampal A, Dedic A et al (2013) Impact of iterative reconstruction on CT coronary calcium quantification. Eur Radiol 23:3246-3252. doi:10.1007/s00330-013-3022-8

27. Takx RA, Willemink MJ, Nathoe HM et al (2014) The effect of iterative reconstruction on quantitative computed tomography assessment of coronary plaque composition. Int $\mathrm{J}$ Cardiovasc Imaging 30:155-163. doi:10.1007/s10554-013-0293-8

28. Willemink MJ, Vliegenthart R, Takx R a P et al (2014) Coronary artery calcification scoring with state-of-the-art CT scanners from different vendors has substantial effect on risk classification. Radiology 273:695-702. doi:10.1148/radiol.14140066

29. Groen JM, Kofoed KF, Zacho M et al (2013) Calcium score of small coronary calcifications on multidetector computed tomography: results from a static phantom study. Eur J Radiol. doi:10.1016/j.ejrad.2012.09.018

30. Hong C, Pilgram TK, Zhu F, Bae KT (2004) Is coronary artery calcium mass related to Agatston score? Acad Radiol 11:286292. doi:10.1016/S1076-6332(03)00714-1 